\title{
PEMBERDAYAAN MASYARAKAT AGROFORESTRY \\ UNTUK PENGEMBANGAN EDUWISATA BERBASIS PERTANIAN \\ DAN KOPI ORGANIK DESA TAWANGARGO KECAMATAN \\ KARANGPLOSO KABUPATEN MALANG
}

\author{
${ }^{1}$ Bambang Yudi Ariadi, ${ }^{2}$ Amir Syarifuddin, ${ }^{3}$ Muhammad Irfan \\ ${ }^{1}$ Jurusan Agribisnis, Fakultas Pertanian dan Peternakan Universitas Muhammadiyah Malang \\ E-mail :bambang_y@umm.ac.id \\ ${ }^{2}$ Jurusan Kehutanan, Fakultas Pertanian dan Peternakan Universitas Muhammadiyah Malang \\ E-mail:amir@umm.ac.id \\ ${ }^{3}$ Jurusan Teknik Elektro, Fakultas Teknik Universitas Muhammadiyah Malang \\ E-mail : irfan@umm.ac.id
}

\begin{abstract}
ABSTRAK
Desa Tawangargo merupakan salah satu Desa Perbatasan di wilayah Kabupaten Malang dan Kota Batu,Secara geografis Desa Tawangargo secara tidak langsung pola hidup dan cara pandang masyarakat lebih tertuju pada pola hidup masyarakat kota, namun demikian adat istiadat serta dinamika masyarakat masih sifat kegotong royongan masih sangat tinggi. Sehingga secara umum masyarakat merasa ikut memiliki, memikirkan bagaiman Desanya menjadi berkembang,maju dan madiri menjadi desa swasembada. Melihat manfaat dari lomba Desa dan Kelurahan adalah salah satu kegiatan Pemerintah yang hakekatnya merupakan upaya untuk mendorong usaha Pembangunan masyarakat atas dasar tekat dan kekuatan sendiri. Kegiatan tesebut sekaligus untuk meneliti dan menilai keberhasilan usaha-usaha masyarakat dalam membangun Desa dan Kelurahan, yang terwujut dalam peningkatan kualitas dibidang kehidupan ekonomi, sosial, politik dan kebudayaan masyarakat serta terpeliharanya lingungan Desayang sejahtera.
\end{abstract}

Kata kunci: Pemberdayaan, Eduwisata, onservasi, Pertanian dan Kopi

\section{PENDAHULUAN}

\section{Analisis situasi}

Desa Tawangargo merupakan salah satu Desa Perbatasan di wilayah Kabupaten Malang dan Kota Batu,Secara geografis Desa Tawangargo secara tidak langsung pola hidup dan cara pandang masyarakat lebih tertuju pada pola hidup masyarakat kota, namun demikian adat istiadat serta dinamika masyarakat masih sifat kegotong royongan masih sangat tinggi.
Sehingga secara umum masyarakat merasa ikut memiliki, memikirkan bagaiman Desanya menjadi berkembang,maju dan madiri menjadi desa swasembada.

Melihat manfaat dari lomba Desa dan Kelurahan adalah salah satu kegiatan Pemerintah yang hakekatnya merupakan upaya untuk mendorong usaha Pembangunan masyarakat atas dasar tekat dan kekuatan sendiri. Kegiatan tesebut sekaligus untuk meneliti dan menilai keberhasilan usaha-usaha masyarakat dalam 
membangun Desa dan Kelurahan, yang terwujut dalam peningkatan kualitas dibidang kehidupan ekonomi, sosial, politik dan kebudayaan masyarakat serta terpeliharanya lingungan Desa yang sejahtera.

Paradikma pembangunan yang terpusat pada rakyat, menempatkan masyarakat atau rakyat sebagai pusat perhatian dan sasaran sekaligus pelaku utama pembangunan,segala upaya pembangunan berusaha mengarah pada penciptaan kondisi dan lingkungan yang memungkinkan masyarakat dapat menikmati kehidupan yang lebih baik dan sekaligus memberi kesempatan yang luas kepada masyarakat untuk melakukan pilihan-pilihan sesuai dengan potensi dan karakteristik yang dimiliki oleh masyarakat Desa Tawangargo.

Sesuai apa yang tertuang dalam Rencana Strategis propinsi Jawa Timur bahwa Kerangka Kontruksi Pembangunan adalah integrasi pertumbuhan, pemberdayaan masyarakat dan pemerataan. Paradigma pemberdayaan masyarakat menjadikan masyarakat sebagai pusat pembangunan baik dalam kontruksi konsep maupun praktek pembangunan yang menyertakan kehendak dan kreatifitas masyarakat, yang mengembangkan kemampuan dan mempertimbangankan penilaian masyarakat terhadap hasil-hasil pembangunan yang telah berjalan.

Pembangunan yang dilaksanakan harus menjamin proses pemerataan sebagaimana konsep pembangunan yang berkesinambungan. pembangunan harus digerakan oleh rakyat dari bawah yang mana pemerintah hanya sebagai fasilitator dan bukan sebagai pihak yang menetukan. Percepatan laju penbagunann dan pengembangan desa, perlu digerakan dan digalakan dengan menciptakan kreatifitas dan aktifitas baru serta semangat masyarakat sehingga tercipta pemerataan kehidupan masyarakat di segala bidang.

Pembangunan desa dan pembangunan masyarakat perlu didorong melalui peningkatan koordinasi dan peningkatan pembangunan sektoral, Pembangunan sumbar daya manusia, pemanfaatan sumberdaya alam dan penumbuhan iklim yang mendorong tumbuhya prakarsa dan swadaya masyarakat sehingga dapat mempercepat pembangunan desa menuju desa yang mandiri, siaga dan desa cerdas yang bertujuan menumbuh kembangkan petensi ekonomi desa, kesiapan seluruh system di desa dalam menaggulangi wabah penyakit, serta tersediaya fasilitas kesehatan yang bisa dijangkau seluruh masyarakat Desa. tersedianya kelengkapan Fasilitas Sekolah dari pendidikan tingkat dasar sampai SMP.

Strategis pembangunan Desa Tawangargo dititik beratkan pada peningkatan sumberdaya manusia termasuk penciptaan iklim yang mendorong tumbuhya kemampuan dan kekuatan sendiri dengan cara menumbuhkan dan mengefektifkan peran serta masyarakat.

Perkembangan lambaga pemberdayaan masyarakat desa (LPMD) sebagai sosialisasi dari peraturan daerah Kabupaten Malang nomor 02 Tahun 2001 tentang pembentukan lembaga kemasyarakatan desa / kelurahan dan sosialisasi dari keputusan presiden Nomor 49 Tahun 2001 tentang penataan lembaga ketahanan masyarakat Desa ( LKMD) atau sebutan lainnya yang telah menunjukan perananya sebagai mitra pemerintah desa dalam aspek perencanaan pembangunan yang bertumpu pada masyarakat.

Secara geografis Desa Tawangargo terletak pada posisi $7^{\circ} 53^{\prime} 35^{\prime}$ Lintang Selatan dan $112^{\circ}$ 53' 41' Bujur Timur. Topografi ketinggian desa ini adalah berupa daratan tinggi yaitu sekitar $700 \mathrm{~m}-1000 \mathrm{~m}$ di atas permukaan air laut. Secara administratif, Desa .Tawangargo terletak di wilayah Kecamatan Karangploso Kabupaten Malang dengan posisi dibatasi oleh wilayah desa dan Hutan. Di sebelah Utara berbatasan dengan Perhutani Di sebelah Barat berbatasan dengan Desa Giripurno kecamatan Bumiaji Kota Batu . Di sisi Selatan berbatasan dengan Desa Pendem Kecamatan Junrejo kota Batu, sedangkan di sisi timur berbatasan dengan Desa Donowarih Kecamatan Karangploso Kabupaten Malang.

Sedangkan Luas Wilayah Desa Tawangargo adalah 654632 Ha. Luas lahan yang ada terbagi ke dalam beberapa peruntukan, yang dapat dikelompokkan seperti untuk fasilitas umum, pemukiman, pertanian, perkebunan, kegiatan ekonomi dan lain-lain. 
Luas lahan yang diperuntukkan untuk pemukiman adalah 198 Ha. Luas lahan yang diperuntukkan untuk Pertanian adalah 204 Ha. Sedangkan luas lahan untuk fasilitas umum adalah sebagai berikut: untuk perkantoran 0.25 Ha, sekolah $2.25 \mathrm{Ha}$, olahraga $0.75 \mathrm{Ha}$, dan tempat pemakaman umum $2.5 \mathrm{Ha}$.

Wilayah Desa Tawangargo secara umum mempunyai ciri geologis berupa lahan tanah hitam yang sangat cocok sebagai lahan pertanian dan perkebunan. Secara prosentase kesuburan tanah Desa Tawangargo terpetakan sebagai berikut: sangat subur $105 \mathrm{Ha}$, subur 95,7 Ha, sedang 3.3 Ha, hal ini memungkinkan tanaman Hortikultura terutama sayur mayur, padi ditambah dengan kopi yang terus dikembangkan penanaman dan pengolahannya

Pertumbuhan dan perkembangan ekonomi masyarakat di desa Tawangargo ditandai dengan munculnya berbagai kegiatan usaha ekonomi produktif,yang dilakukan oleh masyarakat desa Tawangargo,hal ini dapat dilihat dari banyaknya pedagang hasil pertanian yang sangat potensial untuk di kembangkan. Desa Tawangargo sangat setrategis karena berbatasan langsung dengan Kota Batu dan Jalur utama wisata menuju Kota batu sebagaian besar penduduk Desa Tawangargo sebagai Kelompok Tani Kopi ,pegawai Industri, Buruh bangunan. Dilihat dari hal tersebut maka kegiatan ekonomi masyarakat dapat diarahkan untuk berdagang di sarana pasar wisata yang akan dibangun oleh pemerintah desa bekerjasama dengan pihak ke tiga. Adapaun untuk sementara ini wisata yang ada di desa Tawangargo adalah wiasata Pertanian dan wisata air sumber sari.

Pemberdayaan dan penguatan kelembagaan kelompok tani merupakan proses perubahan pola pikir dengan mempersiapkan SDM Kelompok Tani menjadi profesional, baik dalam teknis budidaya (produksi), dalam pengolahan hasil, pemasaran dan pengelolaan organisasi.

Ada tiga faktor yang dapat menjadikan Kelompok Tani profesional, yaitu pengetahuan, keahlian dan moral. Ketiga faktor ini bisa dikuasai Kelompok Tani melalui suatu proses dan tahapan pemberdayaan yang menggunakan sistem, strategi dan metode yang sesuai dengan spesifik lokal; menciptakan hubungan antar
Kelompok Tani yang harmonis, kompak dan kebersamaan. Kondisi ini sangat diperlukan sebagai pendorong dan penumbuh semangat dalam melaksanakan segala aktivitas secara profesional. Untuk ini perlu adanya motivasi dan fasilitasi; mempersiapkan kelembagaan Kelompok Tani yang kuat dan berfungsi.

Bila suatu kelembagaan dibangun atas dasar SDM yang profesional, lalu dikelola dengan prinsip kebersamaan dan difasilitasi dari bawah, maka akan tumbuh menjadi kelembagaan Kelompok Tani yang kuat dan berfungsi dalam melayani anggota. Masalah lain yang sering dihadapi dalam upaya menumbuhkan kelembagaan Kelompok Tani adalah soal kepercayaan anggota kepada kelembagaan tersebut dan pengurusnya. Tanpa ada rasa percaya diri dari anggotanya, maka kelembagaan yang dibangun tidak akan kuat dan tidak berfungsi dengan baik serta berkelanjutan.

Untuk menumbuhkan kemitraan di kalangan kelompok tani terutama Kelompok Tani Kopi dibangun dengan menjalin hubungan kerjasama yang saling menguntungkan antar dua pihak yang bermitra, dengan memenuhi 3 syarat yaitu: kemitraan yang menguntungkan kedua belah pihak; kemitraan yang tidak didasari hubungan belas kasihan, melainkan didasari pada hubungan yang sejajar antara satu pihak dengan pihak lainnya; kemitraan yang dibangun merupakan kerjasama yang profesional. Output dari pemberdayaan dan penguatan Kelompok Tani Kopi melalui Sistem Kebersamaan Ekonomi (SKE) adalah: Kelompok Tani menjadi pandai dan profesional, organisasi Kelompok Tani mandiri dan berfungsi melayani anggotanya, produktivitas kebun tinggi, pendapatan Kelompok Tani meningkat, sistem keuangan transparan, terjalinnya hubungan kerjasama yang harmonis di antara anggota, kelompok dan mitra usaha.

Untuk memudahkan memahami SKE berdasarkan Manajemen Kemitraan, maka dianalogikan sebagai sebuah bangunan rumah (Rumah Idaman Masa Depan). Untuk membangun rumah yang kokoh dan kuat, maka pondasinya harus dibangun dengan kuat yang kemudian dilengkapi dengan tiang-tiang utama 
beserta atap dan plafon serta kamar-kamar sesuai dengan kebutuhan.

Dalam kegiatan pemberdayaan Kelompok Tani Kopi selanjutnya dilakukan dengan pelatihan melalui 3 tahapan yang diselenggarakan oleh Dinas Perkebunan atau institusi yang membidangi perkebunan baik di provinsi maupun kabupaten.

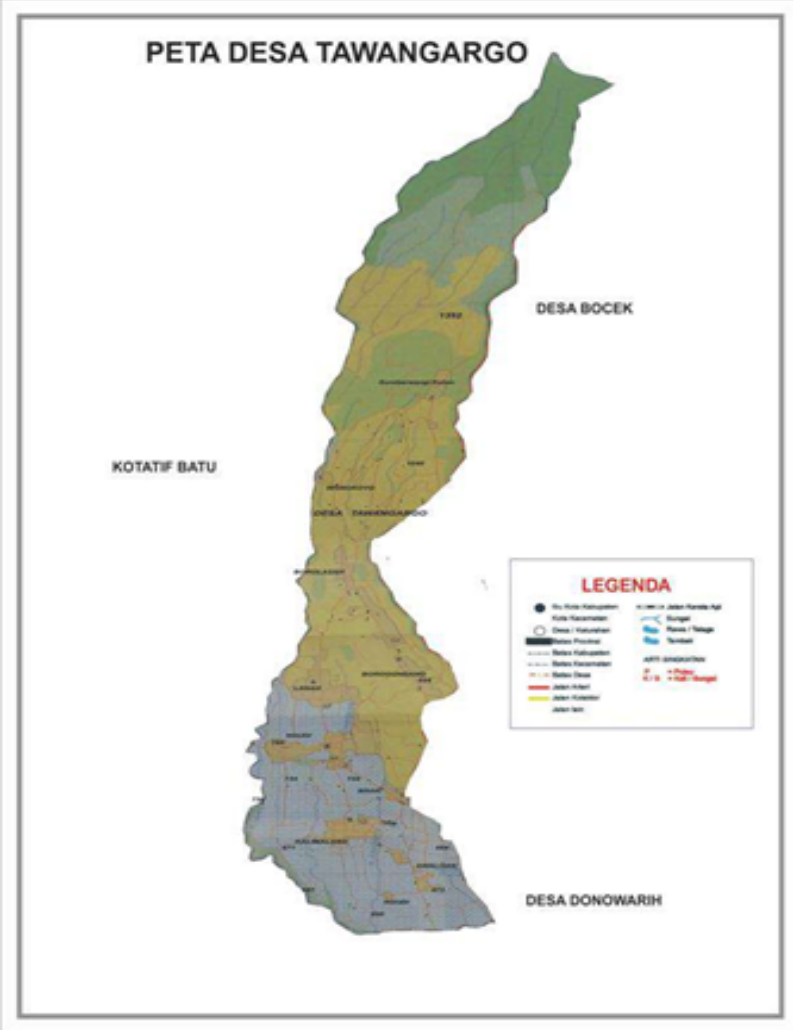

Gambar 1: Peta Desa Tawangargo

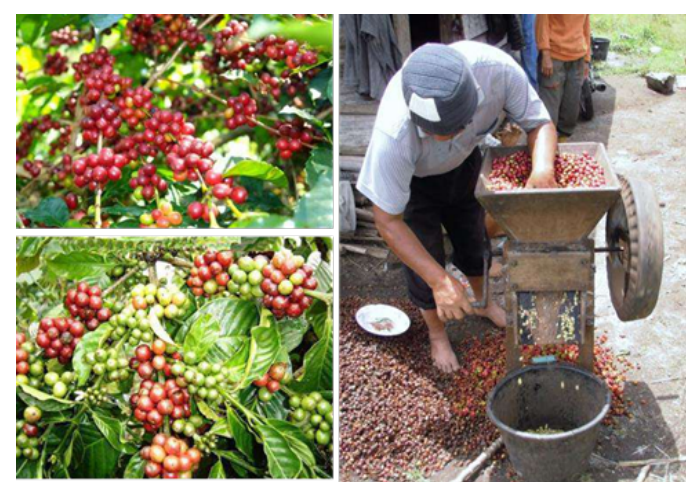

Gambar 2 : Kondisi Hasil Penen Kopi dan Sistem Pengolahan

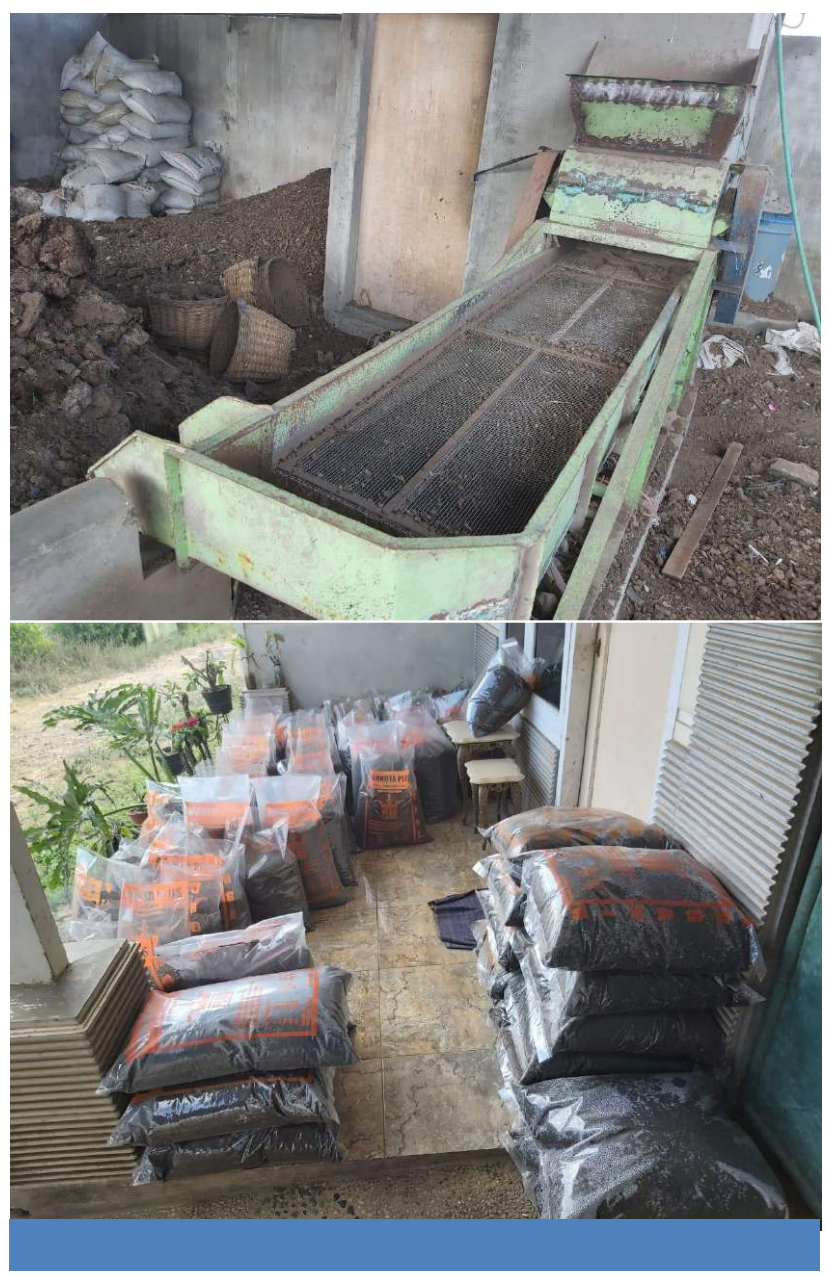

Gambar 3 a : Produktivitas pupuk organik dari Poktan Tawangargo

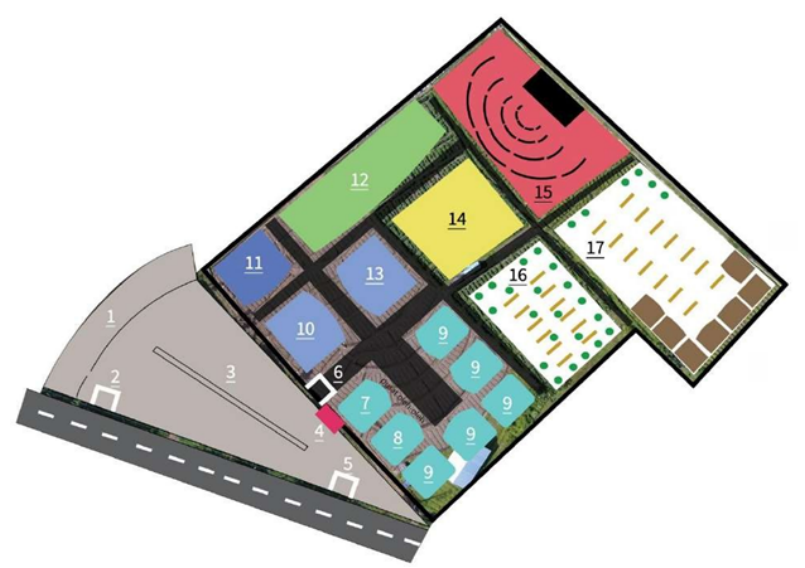

Gambar 3 b : Gambaran Site Plan Eduwisata Tawangargo

\section{Urgensi}

Program PPDM ini bertujuan untuk menjadikan peran perguruan tinggi (UMM) dengan luaran rencana strategis riset unggulan dan pengabdiannya secara lebih riil pada masyarakat desa. Urgensi PPDM ini adalah banyaknya potensi desa Tawangargo di Kecamatan Karangploso, Kabupaten Malang 
yang belum diberdayakan secara optimal, serta kurangnya penguatan sains berupa aplikasi hasil riset dari perguruan tinggi. Disamping itu urgensi lainnya adalah potensi Desa di bidang pertanian organik dan hasil kopi yang belum dikemas secara baik untuk pemasaran dan dikelola secara optimal, sekaligus tantangan untuk menjadi wisata desa karena dengan letak geografis Desa Tawangargo berada pada jalur wisata Kota Batu sehingga diperlukan (pendampingan) penata kelolaan pembangunan sebagai upaya meningkatkan kemandirian ekonomi dan kesejahteraan masyarakat desa Tawangargo. Upaya meningkatkan kemandirian eknomi dan kesejahteraan masyarakat desa Tawangargo ini sesuai dengan RENSTRA Pengabdian pada Masyarakat UMM tahun 2016-2020

Sejalan dengan hal tersebut di atas Pemerintah Kabupaten Malang melalui Kepala Desa dan segenap perangkatnya mengharapkan keterlibatan UMM dalam mewujudkan desa Tawangargo sebagai Desa yang berbasis Eduwisata dengan hasil pertanian dan kopi organik yang direspon oleh pimpinan universitas melalui Direktorat Penelitian dan Pengabdian pada Masyarakat (DPPM) . Oleh karena itu, Universitas MuhammadiyahMalangmemutuskan untuk terlibat dalam penguatan pembangunan di desa Tawangargo tersebut melalui Surat Keputusan Rektor Universitas Muhammadiyah Malang No E.1.a/532/BAA- UMM/V/2017 tentang Penetapan Desa Tawangargo Kecamatan Karangploso Kabupaten Malang sebagai Desa Binaan Universitas Muhammadiyah Malang (SK terlampir).

\section{SOLUSI DAN TARGET LUARAN}

Dari permasalahan desa mitra tersebut di atas maka solusi secara umum adalah:

1. Pendampingan guna Meningkatkan pengetahuan tentang kesehatan lingkungan dan pelestarian

2. Pelatihan pembuatan pupuk organik secara efesien dengan teknologi

3. Pelatihan produksi hasil olahan pertanian dan kopi secara organik

4. Pelatihan packaging/kemasan hasil olahan pertanian dan kopi siap dipasarkan

5. Pelatihan pembukuan dan pemasaran kelompok

6. Membenahi fasilitas umum, jalan desa, penerangan jalan.

7. Perbaikan kualitas lahan dan sistem pengolahan kopi

8. Peningkatan hasil produksi pertanian terutama hasil kopi dengan TTG

9. Meningkatkan ekonomi warga desa di luar hasil pertanian

10. Pembenahan tata kelola lahan kopi yang masih belum tertangani untuk standar tempat wisata dan manajemen pemasaran

11. Perbaikan tata kelola yang lemah berkaitan dengan pencanangan desa wisata, perbaikan arah kebijakan desa wisata Tawangargo

12. Meningkatkan peran masyarakat yang belum berfungsi dalam mempromosikan potensi desa Tawangargo sebagai daya tarik wisatawan

13. Optimlisasi Karang Taruna, sebagai wadah generasi muda yang dapat dilibatkan dalam mengisi pembangunan eduwisata

14. Mendaftarkan merk dagang untuk hasil olahan kopi yang akan diproduksi

15. Membangun sentra-sentra olahan makanan dan minuman hasil pertanian dan kopi organik

16. Pembuatan Profil eduwisata Desa Tawangargo Karangploso

17. Perlunya pendaftaran merk dagang untuk hasil olahan pertanian dan kopi

\section{METODE PELAKSANAAN}

Seperti yang telah dikemukakan di bagian pendahuluan dan skema diatas bahwa dalam program pengabdian PPDM maka yang menjadi prioritas program pengabdian adalah:

\section{Diskusi dan Survey}

Survey dan diskusi beberapa aspek yang meliputi: pembuatan pupuk organik, perawatan tanaman mulai dari pemilihan bibit Kopi, sistem budidaya tanaman Kopi, penanganan penyakit Kopi, pemanenan Kopi, pengolahan pasca panen 
yang meliputi (pengupasan kulit dan proses fermentasi pasca pengupasan) dan pengenalan teknologi pengupasan dengan TTG, pengolahan Kopi menjadi bentuk bubuk dengan dilakukan dengan cara kemasan serta proses pemasaran.

\section{Metode Pelatihan}

Metode ini

digunakan untuk mendemonstrasikan kegiatan-kegiatan yang bersifat aplikatif yang secara langsung dapat disaksikan dan dicobakan oleh seluruh anggota kelompok tani dan sewa lahan untuk demplot pelatihan dengan diikuti kelompok dan masyarakat desa Tawangargo.

\section{Metode Pendampingan}

Mitra/Kelompok Desa Tawangargo menjalani dua tahap diatas dan diyakini memahami dan menguasai materi dan teknologi yang telah dibekali, maka selanjutnya dilakukan pendampingan terhadap kelompok melakukan kegiatan usaha. Kegiatan ini meliputi pendampingan dalam penggunaan pupuk organik berkelanjutan, pendampingan penerapanan TTG proses roasting dan proses pengupasan Kopi, pendampingan pengembangan bisnis bagi kelompok usaha tani Kopi dan pemasaran serta mencarikan mitra bank untuk membantu permodalan guna perluasan usaha.

Sedangkan untuk keberlanjutan program PPDM ini dengan menitikberatkan pada tata kelola lahan guna perancangan dan pembuatan site plan eduwisata pertanian dan kopi organik.
Sebelum desa Tawangargo ditetapkan sebagai desa binaan oleh Sk Rektor Universitas Muhammadiyah Malang No E.1.a/532/BAAUMM/V/2017, Desa Tawangargo telah menjadi bagian dari wilayah/lokasi KKN mahasiswa UMM, sehingga

DPPM UMM sudah mengenal dengan baik lokasi ini sekaligus telah terjalin hubungan kerjasama dengan Kepala Desa dan Camat Kecamatan Karangploso-Kabupaten Malang.

Pada program Program Pengembangan Desa Mitra(PPDM) ini melibatkan 4 dosen dan narasumber yang dipilih berdasar bidang ilmu dan kemampuan yang dimiliki demi menunjang keberhasilan kegiatan. Adapun tenaga ahli yang terlibat meliputi bidang keahlian pemberdayaan masyarakat dan sosial ekonomi pertanian (ketua tim), ilmu tanaman kehutanan mengelola lahan (anggota tim), Ahli Keteknikan bidang Teknologi Tepat Guna dan ilmu komunikasi dan dokumentasi (anggota tim). Susunan Tenaga Ahli dan Tim Program Pengembangan Desa Mitra (PPDM) adalah sebagai berikut:

Sedangkan untuk mitra PPDM di Desa Tawangargo terdiri dari 3 Kelompok Masyarakat dengan jenis kelompok Jasa dan Non Bisnis. Kelompok tersebut sudah pengalaman menjalankan program pengabdian yang terintegrasi dengan pihak Universitas Muhammadiyah Malang di masyarakat Desa Tawangargo.Untuk nama 3 kelompok tersebut adalah :

\begin{tabular}{|c|c|c|c|}
\hline No. & Nama Kelompok & Ketua & Tahun Berdiri \\
\hline 1 & Kelompok Wanita Tawangargo Berdaya & SUKEMI & 2009-sekarang \\
\hline 2 & Kelompok Tani Mulyo & SUJONO & 2009-sekarang \\
\hline 3 & Kelompok Aswaja & RAMAJI & 2011-sekarang \\
\hline
\end{tabular}


Secara umum Struktur organisasi 3 Mitra/ Kelompok adalah sebagai berikut :

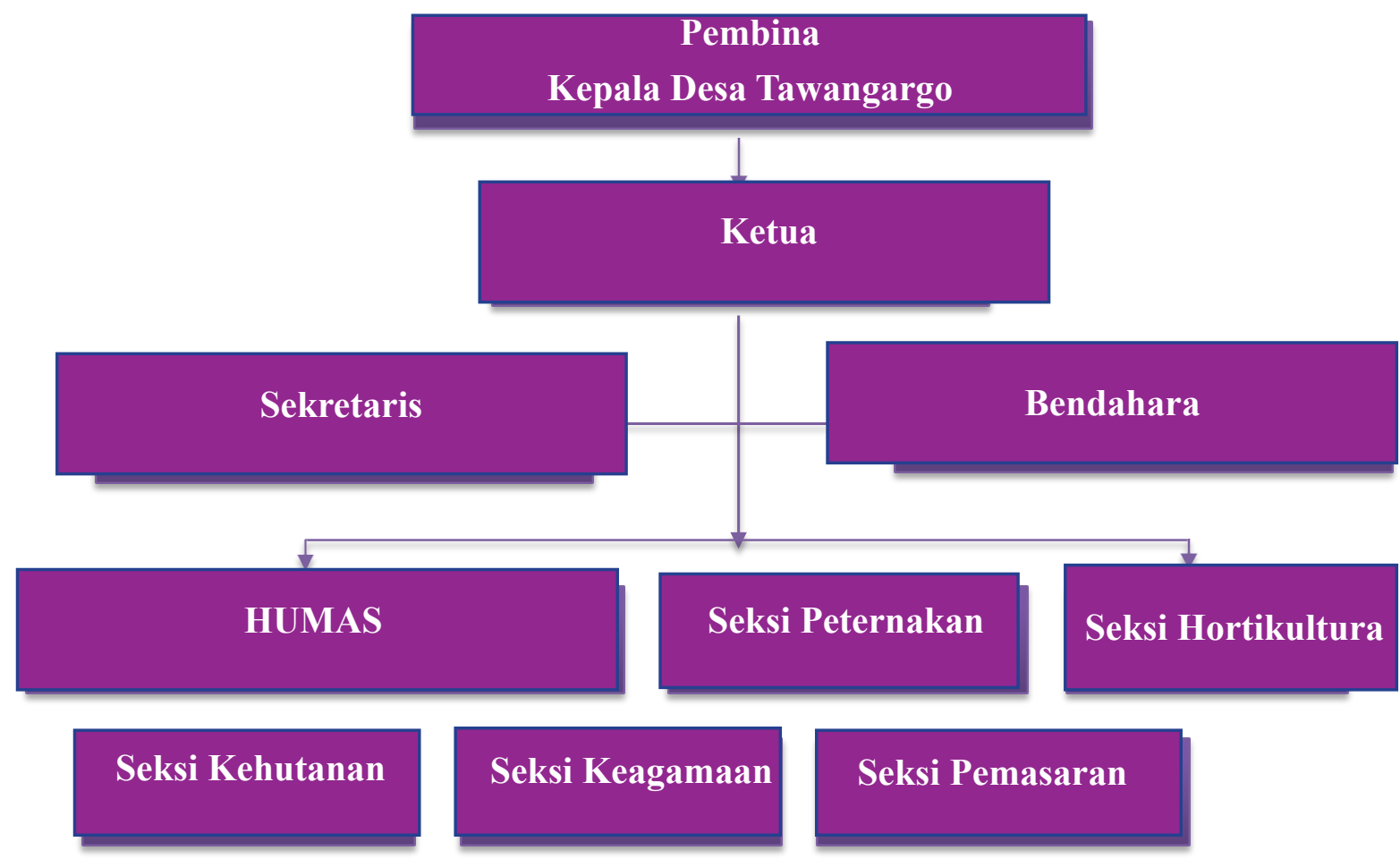

\section{Seksi Taruna Tani}

Ketiga Mitra tersebut adalah kelompok yang bergerak di bidang non bisnis dan jasa dengan menitikberatkan pada kegiatan Pertanian dan jasa di masyarakat dengan kolaborasi kegiatan yang ada di Desa menjadikan Desa Tawangargo menjadi desa yang berpotensi menjadi Desa Eduwisatas dengan hasil pertanian dan olahan Kopi. Sedangkan dengan kemitraan yang terjalin baik dengan partisipasi masyarakat, maka diharapkan adanya peningkatan potensi yang berdaya saing dan tata kelola secara menyeluruh.

\section{REFERENSI}

Djojosumarto, P. 2009. Teknik Aplikasi Pestisida. Kanisius. 211 p. Hadisuwito, S. 2008. Membuat Pup;uk Kompos Cair. AgroMedia. 50 p.

Kardinan, A. 2002. Pestisida Nabati Ramuan dan Aplikasinya. Penebar Swadaya. 88 p.

Kardinan, A. dan A. Ruhnayat. 2003. Budidaya Tanaman Obat secara organik. AgroMedia. $92 \mathrm{p}$.

Kusnaedi. 1999. Pengendalian Hama Tanpa Pestisida. Penebar Swadaya. 94 p.

\section{Seksi Wanita Tani}

Mulat, T. 2003. Membuat dan Memanfaatkan Kascing Pupuk Organik Berkualitas.

AgroMedia. 77 p.

Novizan. 2002. Petunjuk Pemakaian Pestisida. AgroMedia. 124 p.

PANDUAN KKN. 2017 Belajar, Bekerja dan Beramal. Direktorat Penelitian dan Pengabdian kepada Masyarakat. Universitas Muhammadiyah Malang. $100 \mathrm{p}$.

Panduan Pelaksanaan Penelitian Dan Pengabdian Kepada Masyarakat XI DRPM Kemenristekdikti 2017

Sutanto, R. 2012. Pertanian Organik, MenujuPertanian Alternatif dan Berkelanjutan.

Kanisius.218 p.

Suwahyono, U,. 2011. Petunjuk Praktis Penggunaan Pupuk Organik Secara Efektif dan Efisien. Penebar Swadaya : Jakarta

Setyorini, D. 2005. Pupuk Organik Tingkatkan Produksi Pertanian. Warta Penelitian dan Pengembangan Pertanian. Vol.27, No.6 : Bogor 


\section{Dokumentasi Kegiatan}

\section{Pembuatan pupuk organik secara efesien dengan teknologi biofarm}
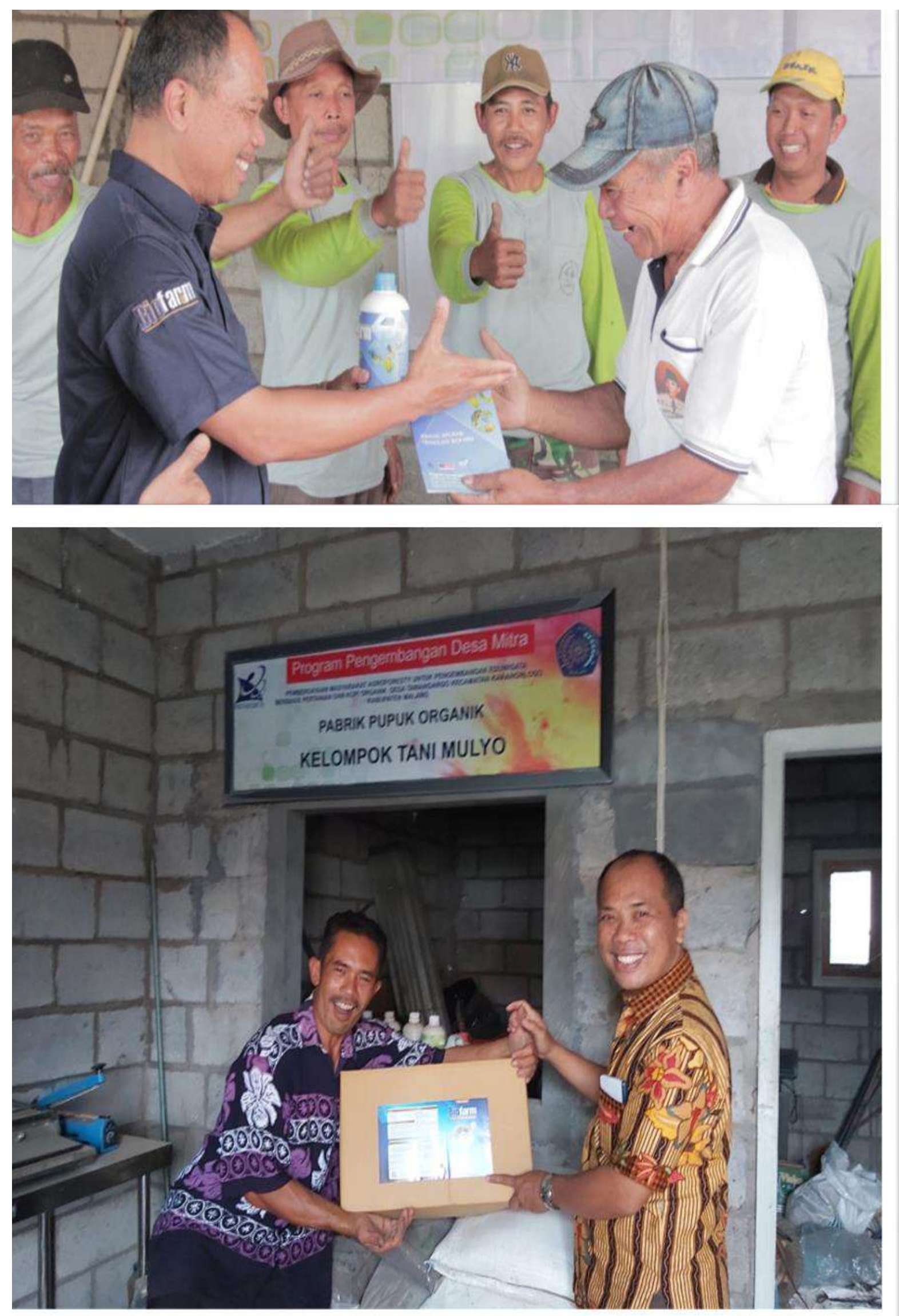


\section{Peningkatan hasil produksi pupuk dengan alat conveyor}
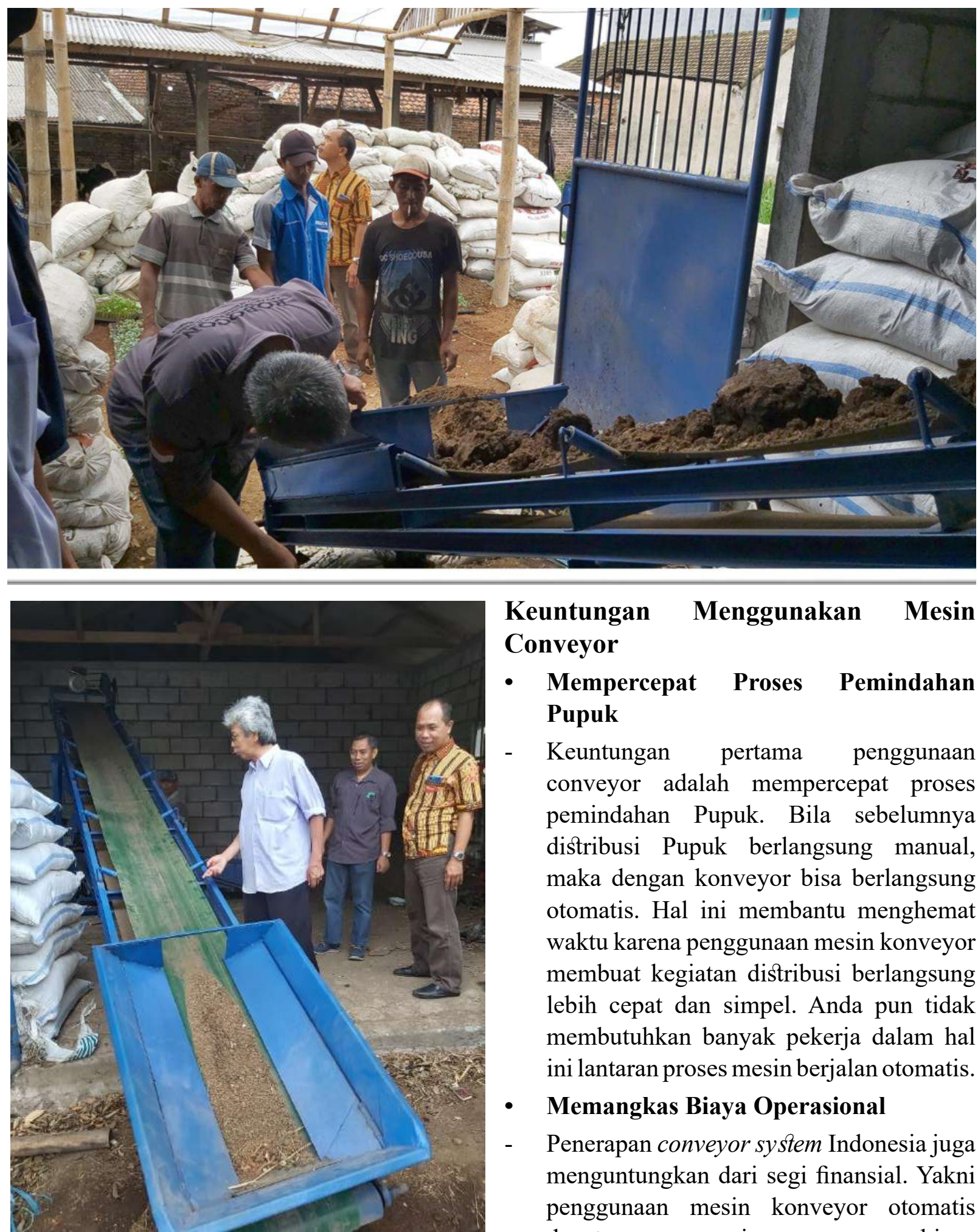

\section{Keuntungan Menggunakan Mesin Conveyor}

- Mempercepat Proses Pemindahan Pupuk

- Keuntungan pertama penggunaan conveyor adalah mempercepat proses pemindahan Pupuk. Bila sebelumnya distribusi Pupuk berlangsung manual, maka dengan konveyor bisa berlangsung otomatis. Hal ini membantu menghemat waktu karena penggunaan mesin konveyor membuat kegiatan distribusi berlangsung lebih cepat dan simpel. Anda pun tidak membutuhkan banyak pekerja dalam hal ini lantaran proses mesin berjalan otomatis.

- Memangkas Biaya Operasional

- Penerapan conveyor system Indonesia juga menguntungkan dari segi finansial. Yakni penggunaan mesin konveyor otomatis dapat mengurangi penggunaan biaya dalam proses produksi hingga proses pemindahan Pupuk. Hanya saja memang industri Anda membutuhkan modal awal untuk menyediakan konveyor dan perawatan 